Politics, 130 Corwin Hall, Princeton, NJ o8544. (Checks may be made payable to the Trustees of Princeton, and in the memo field, donors should write: Stanley Kelley Teaching Prize.)

Larry M. Bartels Princeton University John G. Geer Vanderbilt University Fred I. Greenstein Princeton University

\section{PAUL FABIAN MULLEN}

Paul Mullen passed away at his home in Savannah, Georgia, on December 24, 2009. Paul had been our graduate student and remained our friend. His sense of humor was legendary: mordant, witty, and always to the point. His untimely death brought to an end a life filled with accomplishment. Paul Mullen had managed to fill his life with several careers. His first career had been as an attorney. As well as working in private practice for several years, he also was Assistant Attorney General for the state of West Virginia. He specialized in labor law and was head of the section in the Attorney General's Office responsible for litigation in that field.

After becoming somewhat disenchanted with the practice of law, Paul decided to return to graduate school at the University of Pittsburgh. While there, he specialized in European politics and used his background in law to good effect in studying judicial politics in the United States and the European Union. He received his Ph.D. and a Certificate in West European Studies in 2002. During his time in graduate school, he also spent one semester at the European University Institute on a European Community Studies Association Marshall Fellowship. His experience at the EUI was important, because it allowed him to make contact with major scholars in EU law, such as Giuliano Amato. While there, he became interested in the governance implications of the multilingual nature of the Union, a subject he had planned to develop in his future research.

After leaving graduate school, Paul took his first academic job at Florida International University, where he taught European politics and public law. Using experience gained assisting in writing proposals for the Center for West European Studies at the University of Pittsburgh, he was active in writing proposals for the European Union Center while at Florida
International. He also spent time doing research at the Vrije University of Brussels during his time there. In 2007, Paul moved to Armstrong Atlantic State University, again teaching European politics and public law. In both positions, he demonstrated an outstanding ability to communicate with his students and his commitment to developing their abilities in and out of the classroom.

Paul had a range of research interests that integrated European studies and his knowledge of public law. He was interested in the comparison of American and European law, especially the development of court politics in the European Union. He also was one of the few people to investigate the importance of translation within an increasingly polyglot European Union and how that affected not only implementation, but also the administrative processes within the Union itself. He had a very lively mind that led him in a number of interesting directions and promised an impressive scholarly record.

Everyone who knew Paul Mullen appreciated his amazing sense of humor. His e-mail messages may have had a serious purpose, but they would be filled with political and social commentary that was at once humorous and very pointed. A phone call with Paul was a combination of an academic discussion and a stand-up comedy routine. Perhaps most remarkable was his capacity to retain this good humor in the face of lifethreatening health problems and other challenges. He was facing serious challenges but tried not to let his friends understand just how serious they were.

Paul Mullen's passing is a great loss for his many friends, colleagues, and students. He was an all-too-rare combination of academic ability and personal warmth. He will be greatly missed by us all.

\section{B. Guy Peters University of Pittsburgh Alberta M. Sbragia University of Pittsburgh}

\section{LEONARD S. ROBINS}

Dr. Leonard S. Robins died on November 9,2009 , at the age of 71 , from complications following major surgery. Lenny, as he was known to his friends and colleagues, received his undergraduate degree in political science at the University of Minnesota and went on to study public affairs at the University of Michigan. After several years working in public service and research organizations, he returned to the University of Minnesota for his Ph.D., which was awarded in 1975. In 1982, he took a position in public administration at Roosevelt University in Chicago, where he stayed until his retirement in 2003.

Lenny was enamored by politics. He carefully followed political events at the local, state, and national level and never tired of analyzing and discussing them whenever the opportunity arose. He was also a careful and devoted scholar of public policy. His major interest throughout his academic life was health policy. This began with his Ph.D. dissertation, in which he analyzed the Partnership for Health Act (PL 89-749, 1966). He was an editor and a prime mover of Health Politics and Policy, which went through four revised editions, the last appearing after his retirement. Up until his final sickness, he was hoping that a major health reform act would pass, and that he could add a chapter on it to his book.

Lenny was also very involved in the Jewish community. Until recently, he served on the Board of Directors of the Shari Chesaed Congregation in Minnetonka, Minnesota.

Lenny will be missed by his colleagues, friends, and students, to whom he was a mentor who challenged them to realize their full potential. I personally feel a particular loss. I was his undergraduate advisor, his dissertation advisor, and co-author of his last article, which appeared in print just days before his death.

\section{Robert T. Holt Professor Emeritus University of Minnesota}

\section{ROBERT E. WARD}

Professor Emeritus Robert E. Ward of Stanford University died at the age of 93 on December 7, 2009, in Portola Valley, California. Dr. Ward was a professor of political science and the first director of the Center for Research in International Studies at Stanford University from 1973 to 1987. He was also a senior fellow of the Hoover Institution. Dr. Ward received his B.A. degree from Stanford University in 1936 and his Ph.D. from the University of California (Berkeley) in 1948. During World War II, he served in U.S. Naval Intelligence, receiving the Legion of Merit award. From 1948 to 1973, Dr. Ward was 
on the faculty of the University of Michigan. Professor Ward joined the Stanford faculty in 1973, serving as a professor of political science from 1973 to 1987 and Director of the Center for Japanese Studies from 1965 to 1968 and 1971 to 1973.

His principal areas of professional interest were in comparative politicsespecially Japanese politics-international relations, and political development. He was the author or editor of eight books and many articles in these fields. Dr. Ward served as president of both the American Political Science Association and the Asso- ciation for Asian Studies from 1972 to1973. He was a member of the National Endowment for the Humanities National Council from 1968 to 1973 and President Carter's Commission on Foreign Language and International Studies from 1978 to 1979 . He also served as Chairman of the Board of Directors of the Social Science Research Council, the Japan-U.S. Friendship Commission, and the American Panel of the United States-Japan Conference on Cultural and Educational Interchange (CULCON). Dr. Ward was a fellow of the American Academy of Arts and Sciences and the American Philosophical Society. In 1984, he received the Order of the Sacred Treasure from the government of Japan. He retired from Stanford University in 1987.

Dr. Ward is survived by his daughter, Erica A. Ward of Bloomfield Hills, Michigan, her husband, Ralph J. Gerson, and his granddaughters Stephanie and Maddie Gerson, as well as his brother John W. Ward of Kentfield, California, and a niece and nephews.

Ralph J. Gerson 